\title{
How to Manage Issues Relating to the Use of Trial Experts: Standards for the Introduction of Expert Testimony through Judicial "Gate-Keeping" and Scientific Verification
}

\author{
Richard J. Hunter, Jr. ${ }^{1}$, John H. Shannon ${ }^{1}$ \& Henry J. Amoroso ${ }^{1}$ \\ ${ }^{1}$ Legal Studies, Seton Hall University, South Orange, NJ, United States \\ Correspondence: Richard J. Hunter, Jr., Professor of Legal Studies, Seton Hall University, South Orange, NJ, United \\ States.
}

Received: December 25, 2017

Accepted: January 8, 2018

Online Published: January 10, 2018

doi:10.5430/jms.v9n1p1

URL: https://doi.org/10.5430/jms.v9n1p1

\begin{abstract}
This paper considers issues relating to the introduction of expert testimony in both civil and criminal cases in the American legal system. The paper reviews the Daubert Rule and the standards governing the admissibility of expert testimony in relation to the requirements of peer review and the use of a recognized "scientific method." A number of federal cases will be considered which have attempted to refine and apply the Daubert Rule in a variety of factual circumstances where expert witnesses have been called on to offer their testimony and opinions at various stages of the legal process.
\end{abstract}

Keywords: expert testimony, Daubert Rule, Federal Rules of Evidence, junk science, peer review

\section{Introduction}

Our American legal system often relies on the testimony of so-called expert witnesses to guide the jury in its deliberations. These experts may offer their professional opinions as to facts which will be important to a jury in understanding the nature of a claim or of a defense. Expert witnesses are often critical to both the plaintiff and the defendant, most especially in cases involving products liability, drugs and pharmaceuticals, and toxic torts. Thus, their participation in the trial process must be carefully managed and in some cases orchestrated. The purpose of the study is to investigate the circumstances under which an expert will testify in court by delineating the aspects and origins of the Daubert Rule. The paper will study its current status and its meaning for the introduction of expert testimony (Carr et al., 1997) at trial.

The withdrawal by Matthew Petersen of his nomination to become a federal district court judge, carrying with it a lifetime appointment, was caused in large part by his inability to explain the Daubert Rule to the satisfaction of one of the Republican members on the Senate Judiciary Committee, Senator John Kennedy of Louisiana (Wagner and Demirjian, 2017). The publicity surrounding the hearing and Petersen's subsequent withdrawal has prompted a renewed interest in the underlying theory surrounding expert testimony. The trial lawyer and case manager must be aware of the requirements under which an expert's testimony will be admitted in court and what challenges he or she should expect to confront during the trial process.

\section{Literature Review and Methods}

The paper is based on a careful analysis of the American case law revolving around the creation of detailed rules governing the introduction of expert testimony at trial, most especially the seminal cases of Frye v. United States (1923) and Daubert v. Merrell Dow Pharmaceuticals, Inc. (1993). The article outlines ten cases in which courts have set down rules relating to the application of the Daubert Rule. In addition, the paper relies on numerous law reviews and articles relating to litigation and public health appearing in professional publications.

\section{Daubert v. Merrell Dow Pharmaceuticals, Inc.: The Trial and Appellate Cases}

Jason Daubert and Eric Schuller were born with serious birth defects. They and their parents sued Merrell Dow Pharmaceuticals, Inc., a subsidiary of the Dow Chemical Company, in a California district (trial) court, claiming that the drug Bendectin had caused their birth defects. Merrell Dow successfully removed the case to federal district court on grounds of diversity [litigants from two different states] (Sandler and Levin, 2006), and then moved for a 
summary judgment on the ground that their expert witness, Dr. Steven R, Lamm, whom the trial court had characterized as "a physician and epidemiologist, who is a well-credentialed expert on the risks from exposure to various chemical substances," had submitted an affidavit showing that no published scientific study had demonstrated a link between Bendectin, a prescription anti-nausea drug (Berger, 2005) marketed by respondent, and birth defects during the first trimester of pregnancy. That is, no scientific study had found Bendectin to be a human teratogen (i.e., a substance capable of causing malformations in fetuses).

Plaintiffs Daubert and Schuller submitted their own expert evidence which suggested that Bendectin could cause birth defects. The plaintiffs' evidence, however, was based on in vitro (test tube) and in vivo (live) animal studies, pharmacological studies, and a re-analysis of other studies that had been previously published. At the time of the trial, these methodologies had not yet gained acceptance within the "general scientific community." The District Court stated, "Petitioners' epidemiological analyses, based as they were on recalculations of data in previously published studies that had found no causal link between the drug and birth defects, were ruled to be inadmissible because they had not been published or subjected to peer review" (727 F. Supp. 570, 1989, p. 575).

The District Court granted the defendant's motion for a summary judgment. The court stated that scientific evidence is admissible only if the principle upon which it is based is "sufficiently established to have general acceptance in the field to which it belongs" (727 F. Supp. 570, 1989, p. 570). Upon the dismissal of their complaint, plaintiffs Daubert and Schuller appealed to the Ninth Circuit Court of Appeals.

In 1991, the Ninth Circuit (951 F.2d 1128, 1991), on appeal, found the District Court had correctly granted the defendant's motion for a summary judgment because the plaintiffs' evidence had not yet been accepted as a reliable technique by scientists who had had an opportunity to scrutinize and verify the methods used by those scientists. The Circuit Court, citing Frye v. United States (1923), stated that expert opinion based on a scientific technique is inadmissible unless the technique is "generally accepted" as reliable in the relevant scientific community. The court found that expert opinion based on a methodology that diverges "significantly from the procedures accepted by recognized authorities in the field cannot be shown to be 'generally accepted as a reliable technique'" (951 F.2d 1128, 1991, p. 1130).

The Ninth Circuit emphasized that other Courts of Appeals who had considered the risks of Bendectin had refused to admit the re-analyses of epidemiological studies that had been neither published nor subjected to peer review. Those courts had found unpublished re-analyses "particularly problematic in light of the massive weight of the original published studies supporting [respondent's] position, all of which had undergone full scrutiny from the scientific community" (951 F.2d 1128, 1991, p.1130). Finding that re-analysis is generally accepted by the scientific community only when it is subjected to verification and scrutiny by others in the field, the Court of Appeals rejected petitioners' re-analyses as "unpublished, not subjected to the normal peer review process, and generated solely for use in litigation" (951 F.2d 1128, 1981, p.1131).

In addition, the Ninth Circuit voiced concern that the plaintiffs' evidence appeared to be generated in preparation for the litigation and was not the product of independent (prior) scientific discovery. With the exclusion of the evidence that the plaintiffs had attempted to offer, the Ninth Circuit raised doubts that the plaintiffs would be able to sustain their burden of proof at trial that Bendectin had, in fact, caused the birth defects about which they were complaining.

The United States Supreme Court granted certiorari (506 U.S. 914, 1992) in light of sharp divisions among the several appellate courts (and legal scholars) regarding the proper standard for the admission of expert testimony (compare, e.g., United States v. Shorter (1987) with DeLuca v. Merrell Dow Pharmaceuticals, Inc. (1990)). What was the status of the rules relating to the introduction of expert "scientific" testimony prior to Daubert? Why did the United States Supreme Court agree to hear the case?

\section{Frye v. United States (1923): A Seventy Year Precedent}

In 1923, the District of Columbia Circuit Court of Appeals had decided Frye v. United States (293 F. 1013, 1923). The D.C. Circuit held that evidence could be admitted in court only if "the thing from which the deduction is made is sufficiently established to have gained general acceptance in the particular field in which it belongs."

Defendant Frye had been charged with murder. At his trial, Frye attempted to call an expert witness who was prepared to testify that Frye had taken a systolic blood pressure deception test (a precursor to a lie-detector or polygraph test), and to further testify as to the results of the test, which would presumably bolster the defendant's claim of his innocence. The expert testimony was held inadmissible by the lower court. Frye was subsequently convicted of second-degree murder. On appeal, the court was asked to decide if the evidence, which had not gained general scientific recognition from psychological and physiological authorities, should have been admitted (Linn, 
1999). The Circuit Court decided that in order to be admissible, the evidence must be "sufficiently established to have gained general acceptance in the particular field in which it belongs." In reaching its decision, the Circuit Court determined that although the deception test had a scientific basis,

"[j] ust when a scientific principle or discovery crosses the line between the experimental and demonstrable stages is difficult to define [and] the thing from which the deduction is made must be sufficiently established to have gained general acceptance in the particular field in which it belongs [to be admissible]" (293 F. 1013, 1923, p.1014).

The Circuit Court held that without an "established place in science," the test in question had not "crossed the line between experimental science and demonstrated science," and was therefore inadmissible (293 F. 1013, 1923, p.1047). In the court's view, as the deception test was not "sufficiently established," the testimony related to it was inadmissible, and the lower court was correct to have excluded it.

\section{The United States Supreme Court Rules}

On appeal to the United States Supreme Court, plaintiffs Daubert and Schuller argued that as Congress had adopted the Federal Rules of Evidence in 1975, Frye v. United States (1923), decided more than 50 years earlier, should no longer be the governing standard for admitting scientific evidence in a trial conducted in a federal court (Cox, 1994). The Supreme Court had previously ruled that where a common law rule conflicted with a provision of the Federal Rules of Evidence (1975/2014), the Rules would take precedence over the common law (see, e.g., Madden, 1966). The Supreme Court further found that the text of the Federal Rules did not suggest that Congress had intended to incorporate the Frye rule. As a result, the United States Supreme Court reasoned that Frye was no longer the standard under which expert testimony would be received and evaluated.

The Supreme Court specifically focused on Rule 702 of the Federal Rules of Evidence, which provided (in part):

"If scientific, technical, or other specialized knowledge will assist the trier of fact to understand the evidence or to determine a fact in issue, a witness qualified as an expert by knowledge, skill, experience, training, or education, may testify thereto in the form of an opinion or otherwise..."

A careful reading of the text of Rule 702 indicated that the Rule did not make admissibility of expert testimony depend on its general or wide acceptance. In addition, there was no evidence that Congress had intended to incorporate a "general acceptance" standard into Rule 702. The Supreme Court stated that:

"Given the Rules' permissive backdrop and their inclusion of a specific rule on expert testimony that does not mention 'general acceptance,' the assertion that the Rules somehow assimilated Frye is unconvincing. Frye made 'general acceptance' the exclusive test for admitting expert testimony. That austere standard, absent from, and incompatible with, the Federal Rules of Evidence, should not be applied in federal trials" (509 U.S. 579, 1993, p.589).

\section{What Then Is the Standard Governing Expert Testimony?}

At its core, the tacit rejection of the Frye standard in federal courts and the subsequent application of the Daubert Rule require that the proffered testimony must be "relevant to the task at hand" and that it rests on "a reliable foundation." As such, concerns raised about expert testimony cannot be considered as simply a question of the proper weight of the evidence, but whether the evidence can be introduced in the first place (Faigman, Slobogin and Monohan, 2016).

First, the testimony must encompass scientific knowledge, meaning that the testimony must be scientific in nature and must be grounded in ascertainable "knowledge." The Court noted that science "represents a process for proposing and refining theoretical explanations about the world that are subject to further testing and refinement." The "scientific knowledge" contemplated by Rule 702 had to be arrived at by the scientific method or methodology (Smith, 2015; Bernstein and Lasker, 2015).

Second, the scientific knowledge must assist the trier of fact (either the judge or the jury) in understanding the evidence or in determining a fact in issue in the case, i.e., it must be "relevant to the task at hand." To be helpful to the trier of fact, a "valid scientific connection to the pertinent inquiry as a prerequisite to admissibility" is required.

Third, the admissibility of testimony is governed by Rule 104(a), and the judge must find that it is "more likely than not that the expert's methods are 'reliable' and 'reliably applied to the facts at hand."' The Rules expressly provided that the trial court is required to make the threshold determination whether certain testimony would indeed assist the trier of fact in the manner contemplated by Rule 702. This requirement is most often referred to as the judge's "gate keeper" function" (Cherry and Decker, 1999; Williams, 2003). This entails a preliminary assessment by the judge whether the reasoning or methodology upon which the testimony is based is scientifically valid and whether that 
reasoning or methodology properly can then be applied to the facts in issue. The Supreme Court defined "scientific methodology" as the process of formulating hypotheses and then conducting experiments to test the truth or falsity of the hypotheses.

This preliminary assessment involves the application of a series of "illustrative factors" (not strictly tests) in determining whether the broader criteria had been met. These factors include:

- Whether the theory or technique employed by the expert is "generally accepted" in the scientific community (e.g., Fradella, O'Neill and Fogarty, 2004);

- Whether the theory or technique has been subjected to peer review (Ballantyne, 2017) and publication;

- Whether the theory or technique can be or has been tested (Billauer, 2016);

- $\quad$ Whether the known or potential rate of error is acceptable (Du, 2017); and

- Whether research was conducted independent of the particular litigation or dependent on an "intention to provide the proposed testimony" (Knudsen, 2015).

These considerations do not all have to be met for the evidence to be admitted. It is necessary only that the majority of the tests be substantially complied with in order to validate the introduction of the evidence.

Interestingly, the ruling in Daubert may have been presaged in Laos v. Soble (1972), a case involving the admissibility of the testimony of an expert appraisal witness (Hoyt, Aalberts and Poon, 2010) in a condemnation hearing (White, 1996) arising under the government's power of eminent domain and specifically in scrutinizing a contract to pay that witness a fee "contingent on the success of the litigation." Although decided in a different context, the underlying concerns about admitting expert testimony are still relevant. In Laos, the court stated "Professor Corbin points out that the use of' 'expert' testimony has been subject to grave abuses and that bargains for obtaining same should be under close scrutiny by the court." Daubert expressed this same core concern (cf., Diffley and Rutherford, 2007), not about the issue of compensation, but rather concerning the issue of the admissibility of evidence.

In its Daubert decision, the Supreme Court stressed that its ruling was not one of ascertaining scientific truth, but rather, one of procedure. "Scientific conclusions are subject to perpetual revision. Law, on the other hand, must resolve disputes finally and quickly. The scientific project is advanced by broad and wide-ranging consideration of a multitude of hypotheses, for those that are incorrect will eventually be shown to be so, and that in itself is an advance" (509 U.S. 914, 1993, p.597). Rule 702 was intended to resolve concrete legal disputes and not to settle scientific arguments; and, thus, had to be interpreted in conjunction with other rules of evidence and with other legal means of resolving those disputes.

Interestingly, Popper (1989) had earlier commented on the responsibility of determining whether the preferred evidence is actual science ("scientific knowledge") or is "pseudoscience" which is reflected in the following: "the criterion of the scientific status of a theory is its falsifiability, or refutability, or testability."

Once the evidence is admitted, normal trial procedures, which are based, in large part, on the tactics and strategies employed by the parties themselves, will apply (Hirschman, 2005). For example, the expert will be subject to cross examination within the normal adversary process of a trial (Vidmar, 2005; Finkelstein, 2011). Such cross examination is seen as the proper vehicle to assist in the resolution of any dispute. The Supreme Court stated:

"We recognize that, in practice, a gatekeeping role for the judge, no matter how flexible, inevitably on occasion will prevent the jury from learning of authentic insights and innovations. That, nevertheless, is the balance that is struck by Rules of Evidence designed not for the exhaustive search for cosmic understanding but for the particularized resolution of legal disputes" (509 U.S. 579, 1993, p.597).

Some commentators predicted that as a result of the Court's decision in Daubert, it might be expected that the range of scientific opinion evidence would be expanded. However, instead, many courts have strictly construed the Daubert standards. Surprisingly, the focus shifted from an emphasis on "scientific knowledge" to one of the exclusion of "junk science" (Parker, 1998; Giacomo, 2016) or "pseudoscience" (Shermer, 2011). As a result, several courts have excluded new or experimental techniques and research that the decision might have been expected to deem admissible.

The principles enunciated in Daubert were later expanded in Kumho Tire Co. v. Carmichael (1999), where the evidence in question was offered by a technician and not a scientist (Stilwell, 2000). The technician was prepared to testify that the only possible cause of a tire blowout must have been a manufacturing defect (Hunter, Shannon and 
Amoroso, 2012, p.5), as he could not determine any other possible cause. The Court of Appeal had admitted the evidence on the assumption that Daubert did not apply to technical evidence, but only scientific evidence. The Supreme Court reversed the decision of the Circuit Court saying that the Daubert standard could also apply to merely technical evidence (Mahle, 1999) and extended the reaches of Daubert to "all experts in antitrust and securities litigation."

Since the decisions in Daubert and Kumho Tire, there have been several attempts to codify and clarify the elements embodied in what is known as the "Daubert Trilogy" (Bernstein and Jackson, 2004; Cappellino, 2016). In 2000, Rule 702 was amended to read as follows (Oh, 1997):

"If scientific, technical, or other specialized knowledge will assist the trier of fact to understand the evidence or to determine a fact in issue, a witness qualified as an expert by knowledge, skill, experience, training, or education, may testify thereto in the form of an opinion or otherwise, if (1) the testimony is based upon sufficient facts or data,

(2) The testimony is the product of reliable principles and methods, and

(3) The witness has applied the principles and methods to the facts."

In 2011, after more than a decade of evaluating evidence and the expert who offers the testimony, the Rule was again amended to further clarify the Daubert standard:

"A witness who is qualified as an expert by knowledge, skill, experience, training, or education may testify in the form of an opinion or otherwise if:

(a) The expert's scientific, technical, or other specialized knowledge will help the trier of fact to understand the evidence or to determine a fact in issue;

(b) The testimony is based on sufficient facts or data;

(c) The testimony is the product of reliable principles and methods; and

(d) The expert has reliably applied the principles and methods to the facts of the case."

\section{Daubert and Its Progeny}

Since the Supreme Court's decision in Daubert, a number of federal courts have handed down decisions expanding upon, clarifying, and refining its core ruling (Lorandos, 2017). This section of the paper reviews some of the most important federal court decisions suggested by Seak.com (SEAK, 2017). Each decision is preceded by a brief rendition of the underlying facts of each case to provide the proper context for the decision.

At the outset, it should be recognized that the Daubert Rule only has precedential value in federal cases (Horowitz, 2009). States are free to adopt the Daubert Rule or any other rule in state court proceedings (Bohan and Heels, 1995; Keierleber, 2005; Hepburn, 2012). As Morgenstern (2017) noted, “A state may choose to follow Frye, Daubert, or some combination of the two," creating an anomaly. Morgenstern (2017) continued: "For example, when selecting an expert witness for a case in New York, an attorney has to consider that their expert witness's testimony will be judged by the Frye standard. But in Connecticut, the testimony will be subject to the factors found in Daubert" (Morgenstern, 2017).

\subsection{General Electric v. Joiner}

Summary: After he was diagnosed with small-cell lung cancer, respondent Joiner sued in Georgia state court, alleging, inter alia, that his disease was "promoted" by his workplace exposure to chemical "PCBs" and derivative "furans" and "dioxins" that were manufactured by, or present in materials manufactured by, petitioners.

In General Electric v. Joiner (1997), one of the three cases along with Daubert and Kumho Tire to comprise the "Daubert Trilogy," the U.S. Supreme Court held that a trial judge may exclude expert testimony when the evidence relied on by the expert does not support the expert's conclusion. In Joiner, the expert had relied on animal studies in which mice had been exposed to massive doses of a certain chemical. The expert concluded that the plaintiff, who had been exposed to much smaller doses of the chemical, had a cancer that was caused by the chemical. The expert relied on four studies that were inconclusive in establishing a causal link between that particular chemical and the cancer. The Supreme Court held that the trial court had not abused its discretion by excluding the expert's testimony because the evidence he had relied on did not support the conclusion he had reached.

\subsection{Kumho Tire Ltd. v. Carmichael}

Summary: When a tire on the vehicle driven by Patrick Carmichael blew out and the vehicle overturned, one passenger died and the others were injured. The survivors and the decedent's representative, respondents here, 
brought this diversity suit against the tire's maker and its distributor (collectively Kumho Tire), claiming that the tire that failed was defective.

In Kumho Tire Ltd. v. Carmichael (1999), discussed above, the U.S. Supreme Court held that the Daubert standards apply to all expert witnesses, including engineers, technicians, and non-scientific experts (Imwinkelried, 1996). In Kumho, the plaintiffs had relied on an expert witness (Carlson), whom they had characterized as a "technical" witness, to demonstrate that a tire blowout was caused by a defective tire. The technician cited two factors related to the tire's appearance and wear and tear. The trial court had excluded his testimony on the ground that his theory was not reliable. The Supreme Court upheld the exclusion on the ground that "it would prove difficult, if not impossible, for judges to administer evidentiary rules under which a gatekeeping obligation depended upon a distinction between 'scientific' knowledge and 'technical' or 'other specialized' knowledge"' (526 U.S. 137, 1999, p. 148).

In affirming the findings of the trial court that this particular expert's testimony was unreliable, the Supreme Court explained the following:

"We have found no indication in the record that other experts in the industry use Carlson's two-factor test... to support his conclusions. Nor, despite the prevalence of tire testing, does anyone refer to any articles or papers that validate Carlson's approach. Indeed, no one has argued that Carlson himself, were he still working for Michelin, would have concluded in a report to his employer that a similar tire was similarly defective on grounds identical to those upon which he rested his conclusion here. Of course, Carlson himself claimed that his method was accurate, but, as we pointed out in Joiner, "nothing in either Daubert or the Federal Rules of Evidence requires a district court to admit opinion evidence that is connected to existing data only by the ipse dixit ["he himself said it" as an unproven statement] of the expert" (526 U.S. 137, 1997, p. 157).

\subsection{Weisgram v. Marley Co.}

Summary: Bonnie Weisgram died of carbon monoxide poisoning during a fire in her home. Her son, petitioner Chad Weisgram, individually and on behalf of her heirs (hereinafter Weisgram), brought this diversity action in the District Court seeking wrongful death damages. Weisgram alleged that a defect in a heater, manufactured by defendant (now respondent) Marley Company and located in Bonnie Weisgram's home, caused both the fire and her death.

In Weisgram v. Marley Co. (2000), the United States Supreme Court faulted the plaintiff for relying on only one expert witness when they had notice that the expert's qualifications under Daubert were in question.

After a trial in which the plaintiff's case relied on the testimony of one expert witness, the defendant was denied judgment as a matter of law and later appealed to the U.S. Court of Appeals for the Eighth Circuit. The appellate court considered the qualifications of the plaintiff's expert witness and found that he was unreliable under the Daubert standard (169 F.3d 514, 1999). By excluding the testimony of the expert, the court granted judgment for the defendant, without giving the plaintiff the chance to try the case again with a different expert. On appeal, the plaintiff argued to the U.S. Supreme Court that this had violated their right to a fair trial, because the expert had not been excluded until after the trial during the process of appeal. In response the Court stated the following:

"Since Daubert, moreover, parties relying on expert evidence have had notice of the exacting standards of reliability such evidence must meet. It is implausible to suggest, post-Daubert, that parties will initially present less than their best expert evidence in the expectation of a second chance should their first try fail. We therefore find unconvincing Weisgram's fears that allowing courts of appeals to direct the entry of judgment for defendants will punish plaintiffs who could have shored up their cases by other means had they known their expert testimony would be found inadmissible. In this case, for example, although Weisgram was on notice every step of the way that Marley was challenging his experts, he made no attempt to add or substitute other evidence" (528 U.S. 440, 2000, pp. 455-456).

\subsection{Daubert Revisited}

Summary: Petitioners, two minor children and their parents, alleged in their suit against respondent that the children's serious birth defects had been caused by the mothers' prenatal ingestion of Bendectin, a prescription drug marketed by respondent.

After the Supreme Court's decision in Daubert, the case was remanded for further consideration. The Ninth Circuit stated the following:

"We read [the Daubert] factors as illustrative rather than exhaustive; similarly, we do not deem each of them to be equally applicable (or applicable at all) in every case. Rather, we read the Supreme Court as instructing us to 
determine whether the analysis undergirding the experts' testimony falls within the range of accepted standards governing how scientists conduct their research and reach their conclusions" (43 F.3d 1311, 1995, pp. 1316-1317).

As a result, the Ninth Circuit applied the standards laid down by the United States Supreme Court and once again excluded the plaintiff's experts' testimony on the grounds that none of the experts had based their testimony on pre-existing research relevant to the litigation, that the theories underlying their conclusions were not published in peer-reviewed literature, and that their methodologies did not support the conclusions reached.

\subsection{In re Paoli R.R. Yard PCB Litig.}

Summary: The plaintiffs have lived for many years in the vicinity of the Paoli Railroad Yard ("Yard"), a railcar maintenance facility at which polychlorinated biphenyls ("PCBs") were used in profusion for over a quarter-century. They sued the corporations that have maintained the Yard and sold the PCBs, seeking to recover damages for a variety of physical ailments and for property damage.

In a 1994 case decided in the Third Circuit, In re Paoli R.R. Yard PCB Litig. (1994), the plaintiffs had argued that they needed to only make a prima facie showing that an expert's testimony is reliable. The court, however, clarified that a party need do more than show that an expert is qualified "on his or her face." Rather, a party seeking to introduce the testimony of an expert must show that there are "good grounds" to prove that the expert is in fact qualified. The court further explained:

"This does not mean that plaintiffs have to prove their case twice - they do not have to demonstrate to the judge by a preponderance of the evidence that the assessments of their experts are correct, they only have to demonstrate by a preponderance of evidence that their opinions are reliable. The evidentiary requirement of reliability is lower than the merits standard of correctness. Daubert states that a judge should find an expert opinion reliable under Rule 702 if it is based on "good grounds," i.e., if it is based on the methods and procedures of science. A judge will often think that an expert has good grounds to hold the opinion that he or she does even though the judge thinks that the opinion is incorrect. As Daubert indicates, "[t]he focus must be solely on principles and methodology, not on the conclusions that they generate" (35 F.3d 717, 1994, p. 744).

7.6 Rider v. Sandoz Pharm. Corp.

Summary: Bridget Siharath and Bonnie Rider (plaintiffs) brought this action, alleging that their postpartum hemorrhagic strokes were caused by ingestion of Parlodel.

In Rider v. Sandoz Pharm. Corp. (2002), the plaintiffs presented expert testimony in order to prove that a certain drug caused strokes. The Eleventh Circuit Court of Appeals commented on the nature of the evidence presented by plaintiffs as follows:

"The scientific evidence presented by plaintiffs in support of their theory of causation may be grouped into six categories... Plaintiffs presented four epidemiological studies. Three of the four appear to have found no relationship or a negative relationship between Parlodel and stroke. Another may suggest a positive relationship. Nonetheless, both parties agree that none of the studies present statistically significant results and that the epidemiological evidence in this case is inconclusive" (295 F.3d 1194, 2002, p. 1198).

In discussing the nature of the evidence, the Eleventh Circuit noted that it is "well-settled" that epidemiological evidence is very helpful in toxic tort cases, but that the absence of such evidence is not necessarily fatal to a case. However, absent epidemiological evidence [study of the patterns, causes, and effects of health and disease conditions in defined populations], the court found that in this case the proffered evidence was too "speculative" to be reliable and refused to admit the the evidence under the Daubert standard.

\subsection{Kannankeril v. Terminix International, Inc.}

Summary: The Kannankerils, Dr. Mary Kannankeril, her husband, Charles, and their children, Charlene and Crystal, sued a pest exterminator, the Terminix International Company L.P. ("Terminix"), seeking damages for injuries allegedly arising out of the application of pesticides to their residence.

In Kannankeril v. Terminix International, Inc. (1997), an expert's testimony relating to the harmful effects of organophosphates, the basis for many insecticides, herbicides, and nerve agents (Laubach, 2016), was challenged because that expert had not personally produced any publications on organophosphates. The Third Circuit explained the following:

"... the toxic effects of organophosphates on humans are well recognized by the scientific community. Dr. Gerson's (the expert) opinion is not a novel scientific theory regarding organophosphates. Instead, Dr. Gerson merely reported 
that Dr. Kannankeril exhibited the "signs and symptoms of chronic toxicity related to exposure to chlorpyrifos." Thus, although Dr. Gerson did not himself write on the topic, his opinion was supported by widely accepted scientific knowledge related to the harmful nature of organophosphates" (128 F.3d 802, 1997, p. 809).

The Third Circuit concluded that Dr. Gerson's opinion on causation has a factual basis and was based on scientific theory. Dr. Gerson had based his opinion on Dr. Kannankeril's medical records, Dr. Grober's reports confirming her medical condition, and Terminix's application receipts. He had also relied on general experience and readings, general medical knowledge, standard textbooks, and standard references. This approach was held to be within the parameters of Daubert.

\subsection{Lust v. Merrell Dow Pharmaceuticals, Inc.}

Summary: Peter A. Lust brought a personal injury action against Merrell Dow Pharmaceuticals, Inc. alleging that his birth defect, diagnosed as hemifacial microsomia, was caused by his mother's ingestion of Clomid, a fertility drug manufactured by Merrell Dow.

In Lust v. Merrell Dow Pharmaceuticals, Inc. (1996), an expert witness purported to apply methods that were commonly practiced by other scientists, yet who had reached conclusions that were not reached by the other scientists. After the trial court had excluded the testimony, the party for whom the expert had testified argued on appeal that the court had improperly focused on the conclusions rather than the methods applies. The Ninth Circuit upheld the exclusion of the testimony based on the following reasoning:

"When a scientist claims to rely on a method practiced by most scientists, yet presents conclusions that are shared by no other scientist, the district court should be wary that the method has not been faithfully applied. It is the proponent of the expert who has the burden of proving admissibility. To enforce this burden, the district court can exclude the opinion if the expert fails to identify and defend the reasons that his conclusions are anomalous" (89 F.3d 594, 1996, p. 598).

\subsection{United States v. Bonds}

Summary: The underlying case involved in this appeal stemmed from a murder in which a significant issue was whether blood found at the crime scene had come from the defendant John Bonds. An extensive hearing was held before Magistrate Judge James G. Carr, concluding on September 10, 1990, on the issue of whether evidence of similarities in the DNA in the blood at the crime scene and blood from the defendant could be introduced.

United States v. Bonds (1993) was a criminal case. A defendant challenged the method of DNA identification used by an expert called by the prosecution, arguing that a "different method" of DNA identification would have yielded more accurate and perhaps different results. The Sixth Circuit stated that "Daubert requires only scientific validity for admissibility, not scientific precision." The court allowed the expert's testimony because it satisfied the standard set forth in Daubert, regardless of whether a more accurate test might have existed.

\subsection{City of Tuscaloosa v. Harcros Chemicals, Inc.}

Summary: In the instant case, thirty-nine Alabama municipal entities brought suit in the United States District Court for the Northern District of Alabama, alleging that five defendant chemical companies engaged in a conspiracy to fix prices for repackaged chlorine in Alabama in violation of both federal and state antitrust law.

Finally, in City of Tuscaloosa v. Harcros Chemicals, Inc. (1998), a case involving an alleged conspiracy to fix the prices of certain chemicals, the plaintiff's expert testified that high losing bids may be signals of a conspiracy under relevant antitrust law. The trial court had excluded his testimony, stating that the methodology employed by the expert was not sound because the expert had testified that there was no statistical test to determine that a high losing bid is a signal of a conspiracy. The Eleventh Circuit reversed this finding:

"To put it succinctly, McClave's [the expert] data and testimony need not "show a successful conspiracy" to be admitted under Rule 702 as circumstantial evidence of a conspiracy. As expert evidence, the testimony need only assist the trier of fact, through the application of scientific, technical, or specialized expertise, to understand the evidence or to determine a fact in issue. As circumstantial evidence, McClave's data and testimony need not prove the plaintiffs' case by themselves; they must merely constitute one piece of the puzzle that the plaintiffs endeavor to assemble before the jury" (158 F.3d 548, 1998, pp. 564-565).

\section{Final Commentary and Conclusions}

Numerous courts and commentators have entered the debate on the nature and application of the Daubert Rule (e.g., Polentz, 1996). Besides the United States Supreme Court, decisions from the Third, Eighth, Ninth, and Eleventh 
Circuit have attempted to refine and expand upon the Daubert jurisprudence. An effective summary of these inferential precedents found above (SEAK, 2017) may yield the following observations:

- $\quad$ The evidence must support the conclusion reached (General Electric v. Joiner, 1997);

- $\quad$ Daubert standards apply to all experts, not just scientific experts (Kumho Tire Ltd. v. Carmichael, 1999; Goodwin, 2000);

- $\quad$ Parties should supplement their evidence with additional experts when a crucial expert is being challenged (Weisgram v. Marley Co., 2000);

- $\quad$ Daubert Factors are neither exhaustive nor applicable to every case (Daubert v. Merrell Dow Pharm., Inc., 1995);

- $\quad$ "Good grounds" that an expert is reliable requires more than a prima facie showing of reliability (In re Paoli R.R. Yard PCB Litig., 1994);

- $\quad$ Epidemiological evidence is very important for showing causation in toxic tort cases (Rider v. Sandoz Pharm. Corp., 2002);

- $\quad$ Experts may testify to widely accepted scientific knowledge regardless of whether they have published about that knowledge (Kannankeril v. Terminix International, Inc., 1997);

- $\quad$ Courts may decline to admit testimony based on accepted standards with unorthodox results (Lust $v$. Merrell Dow Pharmaceuticals, Inc., 1996);

- Daubert requires "scientific validity" not "scientific precision" (United States v. Bonds, 1993); and

- $\quad$ Expert testimony must assist trier of fact (City of Tuscaloosa v. Harcros Chemicals, Inc., 1998).

Lorandos (2017, p. 18) notes: “The Daubert trilogy's key concepts distill into a set of 11 reliability criteria applicable to all expert testimony in federal courts and in state courts that have adopted the Daubert standard: Reasoning-Methodology—Validity—Reliability—Empiricism-Hypothesis

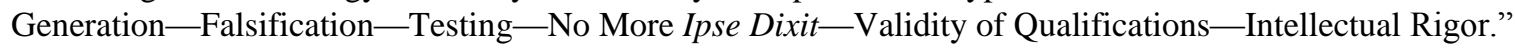

What these and other cases demonstrate is that there is much to be learned about the nature of expert testimony and the standards under which a court should receive and evaluate such testimony.

With the emphasis having shifted from expanding the admissibility of scientific evidence to a court's responsibility to exclude "junk" or "pseudo" science, Daubert and its progeny seem to represent a sensible mid-point of preserving the integrity of the legal process and protecting both plaintiffs and defendants rights in the litigation drama relating to products liability and other areas of law in the United States. Managers and litigation specialists (Sear, 2010; Stevenson, 2014) should pay careful heed to the implications surrounding the introduction and verification of expert testimony in cases alleging either manufacturing or design defects, most especially in the pharmaceutical industry.

\section{References}

Ballantyne, K. N. (2017). Peer review in forensic sciences. Forensic Science International, 277, 66-76.

Berger, M. A., \& Twerski, A. D. (2005). Uncertainty and informed choice: unmasking Daubert. Michigan Law Review, 104(2), 257-289.

Bernstein, D. E., \& Jackson, J. D. (2004). The Daubert trilogy in the states. Jurimetrics, 44, 361-366. Retrieved from https://ssrn.com/abstract=498786

Bernstein, D. E., \& Lasker, E. G. (2015). Defending Daubert: it's time to amend federal rule of evidence 702. William and Mary Law Review, 57(1), 1-48.

Billauer, B. P. (2016). Admissibility of scientific evidence under Daubert: the fatal flaws of "falsifiability" and "falsification". Boston University Journal of Science and Technology Law, 22, 21-87.

Bohan, T., \& Heels, E. (1995). The case against Daubert: the new scientific evidence "standard" and the standards of the several states. Journal of Forensic Sciences, 40(6), 1030-1044.

Cappellino, A. (2016). The Daubert trilogy: navigating the standard for expert witness challenges. The Expert Institute (on line). Retrieved from https://www.theexpertinstitute.com/author/angelica-cappellino/

Carr, M. et al. (1997). Global guide to expert witnesses. International Commercial Litigation, 21, 23-32.

Cherry, M. A., \& Decker, P. (2017). The judge's role as gatekeeper: responsibilities \& powers. Retrieved December 21, 2017, from https://cyber.harvard.edu/daubert/ch9.htm 
Cox, R. E. (1994). Goodbye, Frye; hello, Daubert. The Practical Litigator, 5(2), 15.

Diffley, D., \& Rutherford, S. (2007). Application of Daubert standard in eminent domain cases in light of O.C.G.A. Section 22-1-14: a condemner's perspective. Eminent Domain Section Newsletter, Spring/Summer: 2-3.

Du, M. (2017). Analysis of errors in forensic science. Journal of Forensic Science and Medicine, 3(3), 139-143.

Faigman, D., Slobogin, C., \& Monahan, J. (2016). Gatekeeping science: using the structure of scientific research to distinguish between admissibility and weight in expert testimony. Northwestern University Law Review, 110, 859-904.

Federal Rules of Evidence. (1975/2014). Washington, D.C.: Government Printing Office.

Finkelstein, R. (2011). The adversarial system and the search for truth. Monash University Law Review, 37(1), 135-144.

Fradella, H. F., O'Neill, L., \& Fogarty, A. (2004). The impact of Daubert on forensic science. Pepperdine Law Review, 31(2), 323-361.

Giacomo, W. J. (2016). Scientific proof versus junk science: the court's role as gatekeeper for admitting scientific expert testimony. Westchester Bar Journal, 41(1), 29-40.

Goodwin, R. J. (2000). The hidden significance of Kumho Tire v. Carmichael: a compass for problems of definition and procedure created by Daubert v. Merrell Dow Pharmaceuticals, Inc. Baylor Law Review: 52, 603-646.

Hepburn, R. (2012). Daubert v. Frye: a state-by-state comparison on expert qualification. Retrived from https://encompass.eku.edu/honors_theses/28/

Hirschman, K. L. (2005). Selecting, preparing, and cross-examining expert witnesses (with form). The Practical Litigator, 16(4), 47-60.

Horowitz, D. P. (2009). From the Fryeing pan. Journal - New York State Bar Association, 81(5), 20. Retrieved from https://www.nysba.org/WorkArea/DownloadAsset.aspx?id=43039

Hoyt, R. W., Aalberts, R. J., \& Poon, P. (2010). Daubert and qualification of the appraisal expert witness. The Appraisal Journal, 78(3), 283-291.

Hunter, R. J., Jr., Shannon, J. H., \& Amoroso, H. J. (2012). Products liability: a managerial approach. Create Space (Amazon.com).

Imwinkelried, E. J. (1996). Admissibility of nonscientific expert testimony. Trial, 32(10), 58-62.

Keierleber, J. A., \& Bohan, T. (2005). Ten years after Daubert: the status of the states. Journal of Forensic Sciences, 50(5), 1154-1163.

Knudsen, S. H. (2015). Adversarial science. Iowa Law Review, 100, 1503-1557.

Laubach, K. (2016). Epigenetics and toxic torts: how epidemiological evidence informs causation. Washington and Lee Law Review, 73(2), 1019-1062.

Linn, S. A. (1999). Admissibility v. sufficiency: the dilemma of expert evidence in toxic tort cases. Defense Counsel Journal, 66(2), 227-237.

Lorandos, D. (2017). Expert evidence post Daubert - the good, the bad, and the ugly. Litigation, 43(3), 18-24.

Madden, M. S. (1996). The vital common law: its role in a statutory age. University of Arkansas Little Rock Law Journal, 18, 555-611.

Mahle, S. (1999). The impact of Kumho Tire v. Carmichael. DaubertCounsel.com. Retrieved December 23, 2017, from http://daubertexpert.com/basics_kumho-tire-v-carmichael.html

Morgenstern, M. (2017). Daubert v. Frye- a state-by-state comparison. The Expert Institute (on line). Retrived from https://www.theexpertinstitute.com/author/morgenstern

Oh, P. B. (1997). Assessing admissibility of nonscientific expert evidence under federal evidence rule 702. Defense Counsel Journal, 64(4), 556-567.

Parker, B. R. (1998). Effective strategies for closing the door on junk science experts. Defense Counsel Journal, 65(3), 338-352.

Polentz, M. C. (1996). Post-Daubert confusion with expert testimony. Santa Clara Law Review, 36(4), 1187-1218.

Popper, K. R. (1968). Conjectures and refutations. The growth of scientific knowledge. New York: Harper and Row.

Sandler, P. M., \& Levin, R. B. (2006). Commentary: removal to federal court: look before you leap. Daily Record and the Kansas City Daily News (on line), 1 . 
SEAK. (2017). Admissibility of expert witness testimony: the 10 most important cases citing Daubert. Retrieved 21 , 2017, from https://blog.seakexperts.com/admissibility-expert-witness-testimony-10-important-cases-citing-daubert/

Sear, J. D. (2010). Daubert checklist: tips for posturing your case for successful Daubert challenge. Arizona Chapter Focus, $\quad 4 Q, \quad 5-6 . \quad$ Retrieved from https://www.bowmanandbrooke.com/insights/daubert-checklist-tips-for-posturing-your-case-for-successful-dau bert-challenge-12-01-2010

Shermer, M. (2011). What is pseudoscience? Scientific American (on line), 305(3), 92. Rretrived from https://www.scientificamerican.com/article/what-is-pseudoscience/

Smith, D. G. (2015). The increasing use of challenges to expert evidence under Daubert and rule 702 in patent litigation. Journal of Intellectual Property Law, 22(2), 345-373.

Stevenson, A. H. (2014). How do I challenge an expert witness? Stevenson Criminal Defense, October 20, 2014. $\begin{array}{llll}\text { Retrieved } & \text { December } & 24, & \text { from }\end{array}$ https://www.stevensoncriminaldefence.com/blog/how-do-i-challenge-expert-witness/

Stilwell, R. T. (2000). Kumho tire: the battle of the experts continues. The Review of Litigation, 19(2), 193-231.

Vidmar, N. (2005). Expert evidence, the adversary system, and the jury. American Journal of Public Health, 95(S1), S137-43.

Wagner, J.\& Demirjian, K. (2017). Trump judicial nominee Matthew Petersen pulls out after struggling to answer basic questions. Washington Post (on line), December 18, 2017. Retrieved from https://www.washingtonpost.com/politics/trump-judicial-nominee-who-struggled-to-answer-basic-questions

White, A. P. (1996). Using expert witnesses in condemnation proceedings. The Practical Real Estate Lawyer, 12(1). Retrieved from https://search-proquest-com.ezproxy.shu.edu/docview/196912689?accountid=13793

Williams, M. L. (2003). The history of Daubert and its effect on toxic tort class action certification. The Review of Litigation, 22(1), 181-208.

\section{Cases Cited}

City of Tuscaloosa v. Harcros Chemicals, Inc., 158 F.3d 548 (11th Cir. 1998).

Daubert v. Merrell Dow Pharmaceuticals, Inc., 727 F. Supp. 570 (S.D. Cal.1989) [Record of the trial court].

Daubert v. Merrell Dow Pharmaceuticals, Inc., 951 F.2d 1128 ( $9^{\text {th }}$ Cir. 1991) [Record of the Court of Appeals].

Daubert v. Merrell Dow Pharmaceuticals, Inc., 506 U.S. 914 (United States Supreme Court 1992) [The United States Supreme Court agrees to hear the appeal after dismissal by the Court of Appeals].

Daubert v. Merrell Dow Pharmaceuticals, Inc., 509 U.S. 579 (United States Supreme Court 1993) [Decision of the United States Supreme Court].

Daubert v. Merrell Dow Pharmaceuticals, Inc., 43 F.3d 1311 (9th Cir. 1995) [Decision of the Court of Appeals on reconsideration].

DeLuca v. Merrell Dow Pharmaceuticals, Inc., 911 F.2d 941 ( $3^{\text {rd }}$ Cir. 1990).

Frye v. United States, 293 F. 1013 (D.C. Cir. 1923).

General Electric v. Joiner, 522 U.S. 136 (1997).

In re Paoli R.R. Yard PCB Litig., 35 F.3d 717 (3d Cir. 1994).

Kannankeril v. Terminix International, Inc., 128 F.3d 802 (3d. Cir. 1997).

Kumho Tire Ltd. v. Carmichael, 526 U.S. 137 (United States Supreme Court 1999).

Laos v. Soble, 18 Ariz. App. 502 (Ct. App. Of Arizona, Div. 2 1972).

Lust v. Merrell Dow Pharmaceuticals, Inc., 89 F. 3d. 594 (9th Cir. 1996).

Rider v. Sandoz Pharm. Corp., 295 F.3d 1194 (11th Cir. 2002).

United States v. Bonds, 12 F.3d 540 (6th Cir. 1993).

United States v. Shorter, 809 F.2d 54 (D.C. Cir. 1987).

Weisgram v. Marley Co., 169 F.3d 514 ( $8^{\text {th }}$ Cir. 1999) [Record of the Court of Appeals].

Weisgram v. Marley Co., 528 U.S. 440 (United States Supreme Court 2000). 